\title{
Ulitization of Oil Palm Empty Bunches Waste as a Growth Media for Straw Mushrooms
}

\author{
Liana Dwi Sri Hastuti ${ }^{1 *}$, Erman Munir ${ }^{1}$, Rendra Syahputra Tanjung ${ }^{1}$, Iradani Yupita \\ Ningrum $^{1}$ \\ ${ }^{1}$ Departemen Biologi Fakultas Matematika dan Ilmu Pengetahuan Alam Universitas \\ Sumatera Utara \\ *Email: lianadwisrihastuti@gmail.com
}

\begin{abstract}
Straw Mushroom (Volvariella volvaceae) as well asmushrooms edible otherhave been developed in Indonesia, including North Sumatra as a substitute for animal protein. Mushrooms or also known as button mushrooms are vegetables that are recognized to have high nutritional value, and are even believed to have medicinal properties for various types of diseases so that they have a fairly high selling value. Some studies report that in 100 grams of mushroom, only $0.17 \%$ fat is contained and even better, this fat is not bad fat. Seeing the high demand because of its nutritional value, and its rich content, its taste that is liked by many people, mushroom cultivation has a very promising market value. Basically until now the demand for mushroom continues to increase, but farmers have not been able to meet market needs. good quality start to be limited. Some farmers have started to switch to alternative planting media which is currently mostly practiced, namely oil palm pulp or empty palm oil bunches (TKKS). EFB is a waste that is very easy and is found mostly around palm oil processing factories, whose use has been limited so far as heating materials for boilers and particle wood, many empty bunches have not been utilized. This service aims to provide training in the form of mushroom cultivation using TKKS, as well as provide training in the form of post-harvest handling which is important given the lack of understanding of farmers in production and marketing activities.
\end{abstract}

\section{Keyword: Straw Mushroom, Waste, Oil Palm}

\begin{abstract}
Abstrak
Jamur Merang (Volvariella volvaceae) seperti juga jamur edible lainnya sudah banyak dikembangkan di Indonesia, termasuk Sumatera Utara sebagai pengganti protein hewani. Jamur merang atau dikenal juga sebagai jamur kancing merupakan sayuran yang diakui memilik nilai gizi yang cukup tinggi, bahkan diyakini berkhasiat obat bagi berbagai jenis penyakit sehingga memiliki nilai jual yang cukup tinggi. Bebarapa penelitian melaporkan bahwa dalam 100 gram jamur merang, hanya terkandung sekitar 0,17 \% lemak dan lebih baiknya lagi lemak tersebut bukanlah merupakan lemak jahat. Melihat peminatnya yang cukup tinggi karena nilai gizi, dan kandungannya yang kaya manfaat, rasanya yang disukai banyak orang, budidaya jamur merang memiliki nilai pasar yang sangat menjanjikan. Pada dasarnya hingga saat ini permintaan akan jamur merang terus meningkat, namun petani belum dapat mencukupi kebutuhan pasar Masalah yang dihadapi petani terkait budidaya jamur merang terutama adalah kesulitan dalam memenuhi kebutuhan akan media tanam yang berkualitas baik untuk produksinya dikarenakan bahan baku media tanam berupa dedak atau jerami yang berkualitas baik mulai terbatas. Sebagian petani mulai beralih ke bahan media tanam alternatif yang paling banyak dilakukan pada saat ini adalah ampas tandan sawit atau tandan kosong kelapa sawit (TKKS). TKKS merupakan limbah yang sangat mudah dan banyak ditemukan terutama disekitar pabrik pengolahan minyak kelapa sawit, yang pemanfaatannya selama ini hanya terbatas sebagai bahan pemanas boiler serta kayu partikel saja, banyak tandan kosong yang belum termanfaatkan. Pengabdian ini bertujuan untuk membrikan pelatihan berupa budidaya jamur merang menggunakan TKKS, serta memberikan pelatihan berupa penanganan pascapanen yang penting dilakukan mengingat kurangnya pemahaman petani dalam kegiatan produksi dan pemasaran.
\end{abstract}

Kata Kunci: Jamur Merang, Limbah, Kelapa Sawit 


\section{PENDAhUluan}

Jamur Merang (Volvariella volvaceae) seperti juga jamur edible lainnya sudah banyak dikembangkan di Indonesia, termasuk Sumatera Utara. Sebagai pengganti protein hewani. Jamur merang atau jamur kancing merupakan sayuran yang diakui memilik nilai gizi yang cukup tinggi, bahkan diyakini berkhasiat obat bagi berbagai jenis penyakit sehingga memiliki nilai jual yang cukup tinggi. Bebarapa penelitian melaporkan bahwa dalam 100 gram jamur merang, hanya terkandung sekitar $0,17 \%$ lemak dan lebih baiknya lagi lemak tersebut bukanlah merupakan lemak jahat. Melihat peminatnya yang cukup tinggi karena nilai gizi, serta kandungannya yang kaya manfaat, rasanya yang disukai banyak orang, budidaya jamur merang memiliki nilai pasar yang sangat menjanjikan. Nilai jual jamur merang di pasaran dinilai cukup stabil dan mampu mencapai harga rata-rata per kilogram Rp. 45.000 hingga Rp. 70.000.- dapat dijadikan salah satu komoditas sayuran yang prospektif dan sangat potensial untuk dikomersialkan baik oleh petani maupun pengusaha agribisnis Indonesia khususnya Sumatera Utara. Pada kenyataannya berdasarkan komunikasi langsung dengan petani di Desa Tandukan Raga target ini belum dapat tercapai.

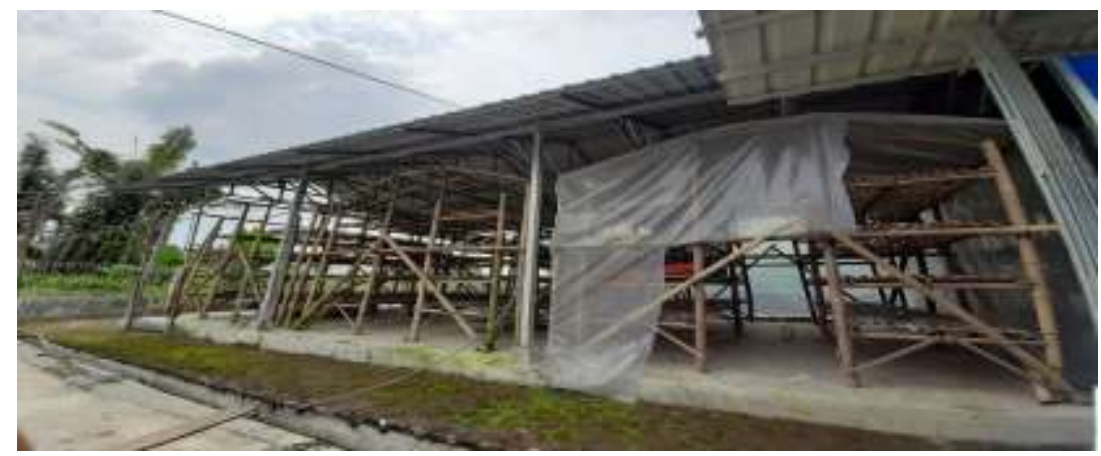

Gambar 1.1. Kondisi rumah jamur (kumbung) di DesaTandukan Raga

Pada dasarnya hingga saat ini permintaan akan jamur merang terus meningkat, namun petani belum dapat mencukupi kebutuhan pasar. Masalah yang dihadapi petani terkait budidaya jamur merang terutama adalah kesulitan dalam memenuhi kebutuhan akan media tanam yang berkualitas baik untuk produksinya dikarenakan bahan baku media tanam berupa dedak atau jerami yang berkualitas baik mulai terbatas. Penggunaan mesin pemotong pada saat panen padi, menyebabkan bagian pangkal hingga bagian tengah batang tanaman padi tertinggal di tanah, sementara bagian inilah yang paling bai kuntuk media tanam jamur merang. Sebagian petani mulai beralih ke bahan media tanam alternatif yang beberapa diantaranya yang sudah dilakukan petani jamur merang adalah menggunakan serbuk gergaji, kapas dan yang paling banyak dilakukan pada saat ini adalah ampas tandan sawit atau tandan kosong kelapa sawit (TKKS).

Beberapa percobaan dengan menggunakan TKKS sebagai media tumbuh jamur merang terbukti sangat baik untuk pertumbuhannya. TKKS mengandung bahan organik serta unsur hara yang dapat dimanfaatkan sebagai media pertumbuhan jamur merang. Sebelum digunakan TKKS sebagai media tumbuh, tankos di komposkan terlebih dahulu serta dilakukan penambahan unsur hara lain berupa dedak dan kapur. Sebagai jamur yang tergolong saprofit yang mampu tumbuh pada substrat organik dari hewan maupun tumbuhan yang sudah mati, jamur ini akan dengan mudah mengubah substrat tempat tumbuhnya menjadi zat yang mudah diserap. Oleh karenanya Jamur merang dapat tumbuh pada media berupa limbah organik seperti tandan kosong kelapasawit (Fuadiet al., 2016). TKKS merupakan limbah yang sangat mudah dan banyak ditemukan terutama disekitar pabrik pengolahan minyak kelapa sawit, yang pemanfaatannya selama ini hanya terbatas sebagai bahan pemanas boiler serta kayu partikel saja, banyak tandan kosong yang belum termanfaatkan. Pengabdian ini bertujuan untuk membrikan pelatihan berupa budidaya jamur merang menggunakan TKKS, serta memberikan pelatihan berupa penanganan pascapanen yang penting dilakukan mengingat kurangnya pemahaman petani dalam kegiatan produksi dan pemasaran, sehingga kurang 
mengakomodir keinginan dari para konsumen dimana pengembangan jamur merang harus mempertimbangkan aspek keunggulan komparatif dan kompetitif, sehingga kebutuhan pasar dapat terpenuhi dengan harga yang relatif tinggi

\section{METODE PELAKSANAAN}

Berdasarkan permasalahan yang telah dikemukakan diatas, maka dalam kegiatan Program Pengabdian Kepada Masyarakat ini metode pendekatan yang digunakan adalah metode survey, metode interview, sosialisasi (penyuluhan), pelatihan pembuatan media terkait fermentasi (pengomposan),sterilisasi media tumbuh serta mengadakan pendampingan.

Dari permasalahan yang telah dikemukakan maka untuk mencapai tujuan yang diharapkan, metode pendekatan yang ditawarkan untuk mengatasi masalah tersebut secara operasional adalah sebagai berikut:

a. Merekam data produksi serta pemasaran dari para petani jamur merang di sekitar Desa Tandukan Raga serta kabupaten.

b. Memberikan penyuluhan tentang cara budidaya jamur merang dengan menggunakan tankos (tandan kosong) kelapa sawit (TKKS).

c. Memberikanpenyuluhan tentang manajemen pemasaran jamur merang sperti membuat kemasan (packaging) merk dan kemungkinan pengembangan usaha baik dengan mengembangkan metode yang sedang dilakukan maupun metode yang berkembang dan trend pada masa sekarang menggunakan media online.

\section{HASIL DAN PEMBAHASAN}

\subsection{Hasil}

Hasil yang diperoleh dari pengabdian kepada masyarakat ialah sebagai berikut.

1. Pembuatan kompos dari tandan kosong kelapa sawit

Telah dilakukan pelatihan pembuatan kompos dari tandan kosong kelapa sawit sebagai media pertumbuhan jamur merang.
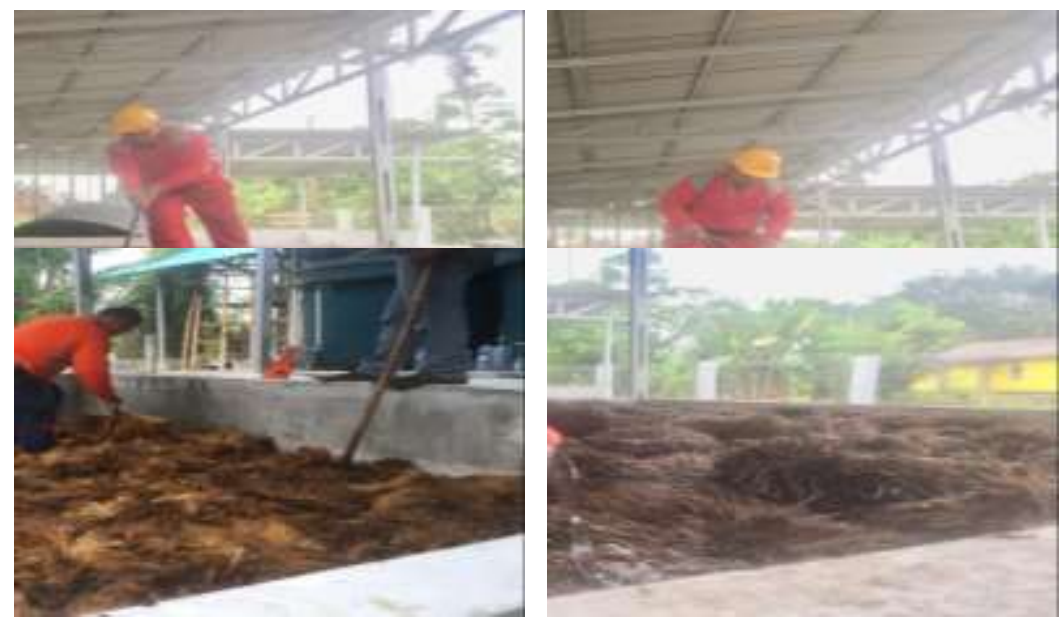

Gambar 3.1. Pengomposan tandaan kosong kelapa sawit

2. Pelatihan sterilisasi kumbung

Telah dilakukan pelatihan sterilisasi kumbung jamur merang sebagai upaya dalam pencegahan terjadinya kontaminasi. Kumbung dengan media tanam ditutup dengan plastik transparan yang 
tebal, kemudian dialiri uap selama 4 jam. Setelah dingin ditaburi dengan bibit, lalu kemudian ditutupi dengan terpal plastik

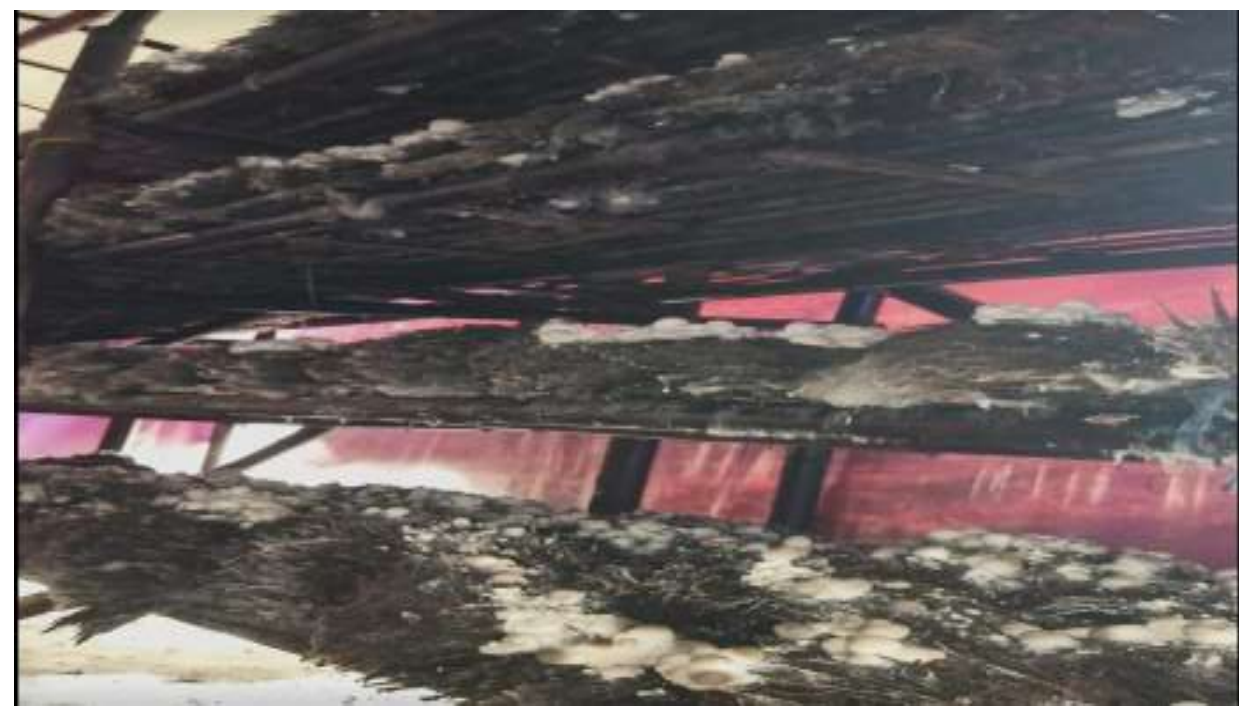

Gambar 3.2 Tempat kumbung yang sudah disterlisasi

3. Pemanenan dan pengemasan (packaging) jamur merang

Telah dilakukan inovasi dalam kemasan jamur merang sebagai upaya meningkatkan kualitas dan daya jual jamur merang terhadap masyarakat.

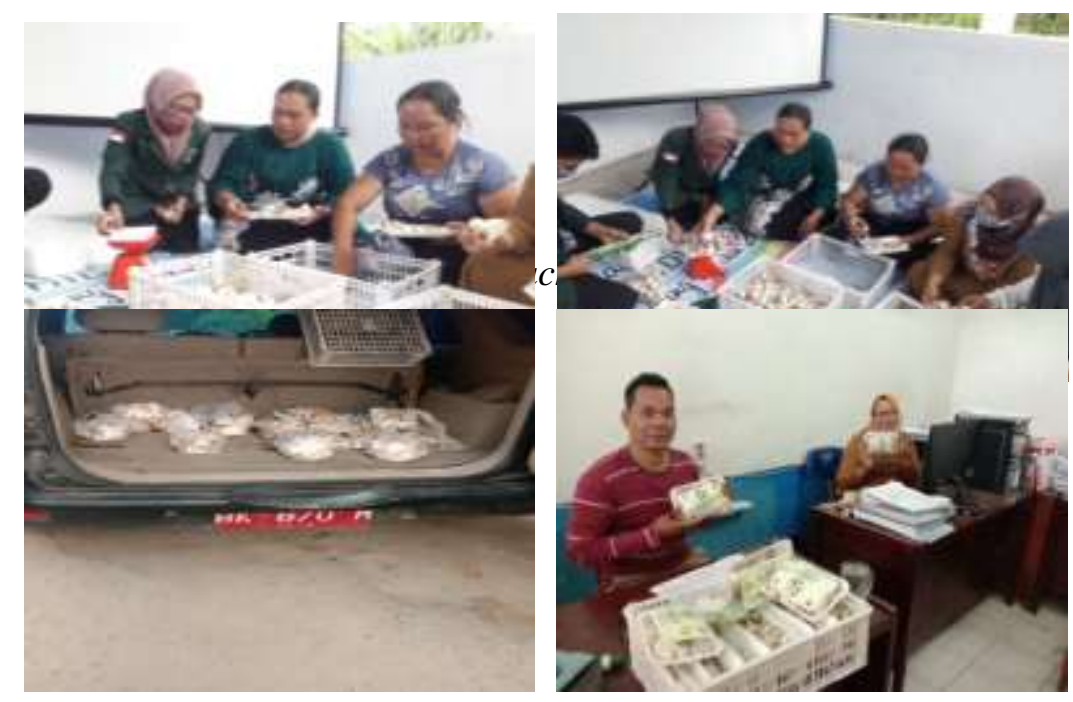

Gambar 3.3 Perbedaan tampilan jamur merang sebelum dan sesudah inovasi kemasan 
Berdasarkan inovasi kemasan yang telah disosialisasikan, didapatkan perbandingan penjualan harga jamur merang sebagai berikut

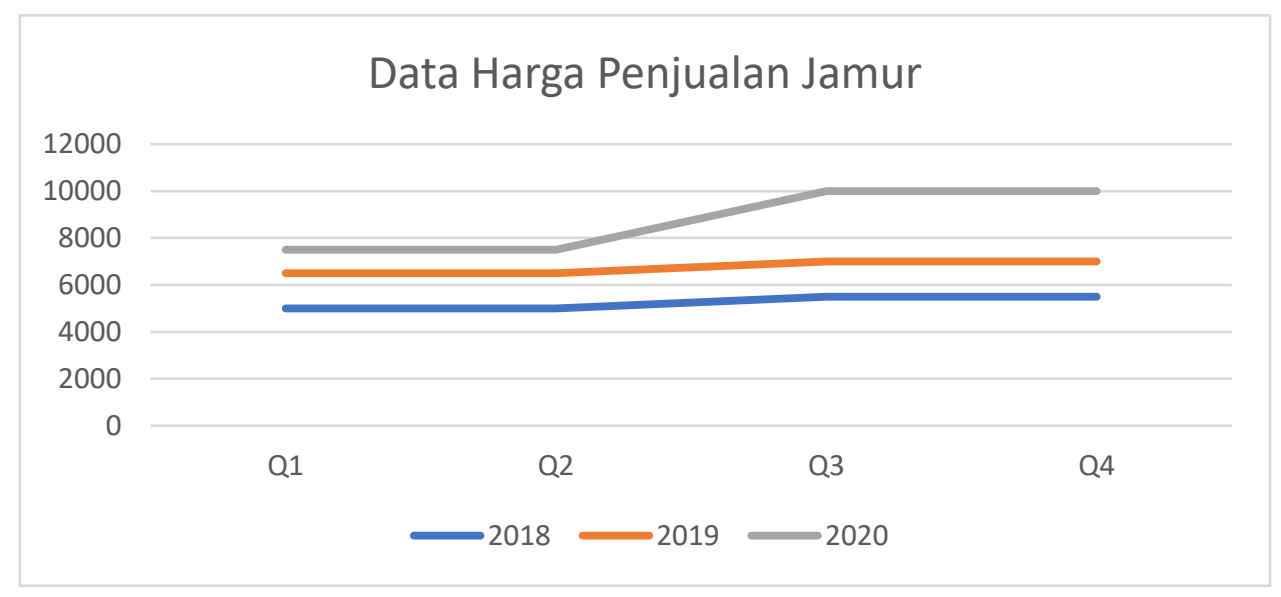

Gambar 3.4 Harga Penjualan Jamur dengan berat 250 gram secara kuatral (dalam rupiah)

Pengabdian masyarakat ini dimulai pada Juli 2020 (Q2) hingga Oktober 2020 (Q3) dan penjualan jamur yang dapat dimakan diperoleh seperti terlihat pada tabel di atas. Terlihat harga jual jamur merang menggunakan plastik biasa dengan berat 250 gram jamur yang dapat dimakan berkisar Rp. 5.000 sampai Rp. 7.500. Sedangkan dengan inovasi berupa packaging menggunakan sterofoam, cling wrap dan stiker harga jamur dengan bobot yang sama adalah Rp. 10.000. Hal ini menunjukkan dengan adanya inovasi dalam bentuk kemasan maka nilai jual dan minat masyarakat akan meningkat. Hal tersebut sejalan jamur yang paling banyak digunakan untuk berbagai bahan makanan seperti campuran sop, pizza, pasta, dan lain-lain. Rasa, tekstur dan kandungan gizinya yang tinggi menyebabkan jamur semakin banyak dimanfaatkan dan nilai ekonominya semakin meningkat. Jamur membutuhkan persyaratan lingkungan khusus serta media tanam dan pemupukan. Media tanam yang biasa digunakan adalah ampas kelapa sawit, ampas tebu, ampas karton, limbah kapas dan lain sebagainya. Limbah yang digunakan harus bebas kontaminasi, sehingga hanya jamur yang ditanam [9]. Hal di atas perlu ditekankan kepada petani bahwa pemasaran secara umum diartikan sebagai suatu proses yang menghasilkan aliran produk, dalam hal ini jamur tiram, secara fisik dan ekonomi dari produsen melalui perantara ke konsumen. Hal ini penting dilakukan untuk menginformasikan kepada masyarakat tentang produk olahan jamur yang dapat dimakan, baik petani jamur itu sendiri, pedagang maupun pengguna sehingga kebutuhan jamur yang dapat dimakan semakin meningkat, dan petani terpacu untuk menghasilkan jamur yang lebih baik dari segi kuantitas dan kualitas. Sehingga mampu menggaet pasar baik pasar tradisional, pasar modern, maupun penjualan on line. Dalam hal pengemasan produk jamur segar dan kering, petani dan pedagang juga perlu memperhatikannya, karena itu salah satu strategi pasar. Strategi seperti memasukkan salah satu resep pada kemasan, juga menjadi daya tarik. Seperti kita ketahui bahwa pengertian pasar secara sederhana adalah pemenuhan kebutuhan pelanggan akan keuntungan, sehingga dua tujuan utama pemasaran adalah menarik pelanggan baru dengan tetap menjanjikan nilai unggul dan mempertahankan pelanggan saat ini dengan memberikan kepuasan.

\section{KESIMPULAN}

Berdasarkan survey, beberapa kegiatan berupa penyuluhan baik dalam bentuk pengetahuan maupun teknologi, petani merasa sangat antusias dalam upaya meningkatkan produksi pasca panen dengan memperhatikan kualitas kemasan, serta mulai melirik untuk menjerat konsumen dengan memasarkan jamur merang dalam bentuk kering. Pembeli atau konsumen, dapat memperoleh jamur 
tiram dengan beberapa pilihan bentuk, segar, kering atau siap jadi. Berdasarkan data yang diperoleh dari koresponden dapat disimpulkan bahwa hasil panen jamur merang berjalan stabil dan cenderung meningkat. Sementara permintaan akan jamur merang cenderung tinggi.

\section{UCAPAN TERIMAKASIH}

Ucapan terima kasih kepada Lembaga Pengabdian Pada Masyarakat (LPPM) USU yang medanai Program ABDIMAS Mono Tahun Reguler Universitas Sumatera Utara Tahun 2020. Terima kasih kepada Kementerian Lingkungan Hidup dan Kehutanan dan Dinas Lingkungan Hidup Provinsi Sumatera Utara, yang bersedia berkerja sama dengan tim ABDIMAS terutama dalam kemudahan akses kumbung jmaur tiram, media tanam dan bibit. Kepada mahasiswa dan alumni yang terlibat di lapangan selama program berlangsung

\section{DAFTAR PUSTAKA}

Alex M. 2011. Meraih Sukses dengan Budidaya Jamur Tiram, Jamur Merang dan Jamur Kuping. Yogyakarta: Pustaka Baru Press.

Djarijah NM, Djarijah AS. 2001. Budidaya Jamur Tiram. Kanisius, Yogyakarta. Hal. 9, 14, 15, 47.

Downey WD, Ericson SP. 1987. Menejemen Agribisnis Ed. Ke-2. Penerjemah Ganda Rochdiyat, S dan Alfonsius Sirait, Jakarta. Erlangga.

Ichsan CN, Harun F, Ariska N. 2011 Karakteristik Pertumbuhan dan Hasil Jamur Merang (Volvariella volvaceae L.) Pada Media Tanam Dan Konsentrasi Pupuk Biogreen yang Berbeda. J. Floratek 6: 171-180.

Isnaeni W. 2010. Budidaya Jamur Konsumsi. Yogyakarta: Lily Publisher.

Martawijaya EI, Nurjayadi MY. 2010. Bisnis Jamur Tiram di Rumah Sendiri. IPB Press: Bogor.

Rahmat, Suryani, Nurhidayat. 2011. Untung Besar Dari Bisnis Jamur Tiram. Agromedia Pustaka: Jakarta

Rismunandar, 1984. Mari Berkebun Jamur. Ternate. Bandung.

Soenanto, Hardi. 2000. Jamur Tiram Budidaya dan Peluang Usaha. Semarang: Aneka Ilmu.

Soenarto, 2004. Prinsip-prinsip Pemasaran. Yogyakarta; Penerbit Amus

Suprapti S. 1988. Pengaruh penambahan dedak terhadap produksi jamur tiram. Jurnal Penelitian Hasil Hutan 5 (6): 337-339

Wibawa MS. 2015. Analisis Rantai Pasok jamur Tiram di Kota Denpasar. [Tesis]. Program Pascasarjana Universitas Udayana, Denpasar.

Winarni, Inggit. Rahayu, Ucu. 2002. Pengaruh Formulasi Media Tanam Bahan Dasar Sebuk Gergaji terhadap Produksi JamurTiram Putih (Pleurotusostreatus). Jurnal Jurusan Pendidikan Biologi, MIPA Universitas Terbuka. 